\title{
Student Marks Reporting System via Email and SMS
}

\author{
Abirami V, Narayana K.E, Chandhnee P, Anandh V
}

\begin{abstract}
The Student Marks Reporting System allows the teachers to report the student's academic performance to their parents via electronic mail and short message service. Further the system also sends the short message in Tamil so that those parents who aren't that familiar with English. The text message is sent to the contact number and email that is specified in the file uploaded.
\end{abstract}

Index Terms-PHP, MySQL, HTML, CSS

\section{INTRODUCTION}

A report can be very useful when one wants to get a quick view of the data. In case of educational institutions, the institutions may want to send reports on the student's academic performance to parents. It will become a very tedious process. Here comes the need for an automatic report generator. The idea is to send the academic performance of the student to parents via email and as a short message service in Tamil Language.Parent teacher interaction is very important not only in schools but also in any educational institution for that matter. We have seen over the years that the process of notice boards, important notification about academics has been carried out manually almost across all educational institutions. This traditional system requires a manual work of writing notifications, taking printouts, displaying it on notice boards and also requires students to watch it regularly. A lot of paper work is involved for that matter and there are possibilities of errors. This system provides a way to overcome all these difficulties with a single button click.

\section{LITERATURE SURVEY}

S.R.Bharamagoudar1, Geeta R.B.2, S.G.Totad, proposed a Student Information Management System (SIMS) that provides a simple interface for maintenance of student information which is used by educational institutes or colleges to maintain the records of student easily. The creation and management of accurate, up-to-date information regarding a student academic career is critically important in the university as well as colleges. [1]

Amita Dhale, Madhav Mistry, Tushar Zore, the proposed application provides a generalized solution to monitor the works that are carried out by a College for managing it.

Abirami V, Computer Science and Engineering, Rajalakshmi

Engineering College, Chennai, India

Chandhnee P,Computer Science and Engineering,Rajalakshmi Engineering College,Chennai,India

Anand V, Computer Science and Engineering, Rajalakshmi Engineering College, Chennai, India

Narayana K.E, Assistant Professor, Computer Science and Engeering,

Rajalakshmi Engineering College, Thandalam, Chennai, India
"Smart Connect" provides a simple interface for maintenance of student information. It deals with all kinds of student details, academic related reports, college details, course details. [2]

Pallavi Mohadikar, Nasrin Mulani, Afnan Shaikh, Rachna Sable, proposed how the concept of web services will be useful for communication between remote server and Android mobile application. With the help of this application parents are able to access all the details regarding their ward. All the data are stored securely on SQL servers managed by the college administrator and ensure highest possible level of security. [3]

Dr. D. Asir Antony Gnana Singh, Dr. E. Jebamalar Leavline , P. Meera Vijayan, this application allows the users to mark attendance though mobile devices and to keep in touch with students, the teacher to mark and edit the attendance and also to add the marks in the system database for further retrieval. It gives prior information to students as soon as their attendance goes below the specified percentage through an alert message. [4]

Ruchi Yadav, Pradnya Ramteke, Anjali Wanjari, Abha Dongre \& Prashant Verma, proposed that it is a real time monitoring system which allows parents to check attendance and academics records of their ward. It also helps college administrative people to maintain student related information. Mobile phone seems to be an asset most individuals' posses, and take almost everywhere with them, it is therefore means of bringing information to them faster, easily and on the move. [5]

Sanyukta Vinod Pachkawade, Rakshanda Pawan Poddar, Pragati Ganesh Bhokare, Avadhut Ashok Mendhe, Prof.Jitendra S.Saturwar, the paper explains that Now-a-days the information to parents regarding their ward is provided through post cards or SMS, but these techniques are very time consuming and lengthy. The application provides a solution through a simple interface for maintenance of student information and also helps parents to get detailed information regarding their ward such as attendance. This application is created to show the attendance of a student to their respective parents directly on their mobile. Each individual parent will be provided with the details of his/her ward only.

Vishwakarma R Ganesh, Android College Management system is an android application which is helpful for students as well as the colleges. In the existing system all the activities are done manually. It is very costly and time consuming. In this proposed system, student can view results using Android phones. The data will be stored in the college server. The 
faculty can login into their college account through the app itself and update the academic result. In this system, students have easy access for viewing the marks, provided their authentications are correct and they are not permitted to change/update the marks.

\section{EXISTING SYSTEM}

The existing systems send text messages only in a common language which is English. There are systems which require the parent to login and check the marks which make it even more difficult. The cons involved are listed below:

i. Complex as it involves the entire student database.

ii. The text message is only in English.

iii. Does not involve a single class data.

\section{PROPOSED SYSTEM}

The proposed system allows the user to upload a file that is in CSV format. After uploading the user can add student details through register student option. The check details module allows the user to view the details of a particular student by giving their roll number. The system also sends email and SMS (in Tamil) to the email id and contact number that is specified in the input file.

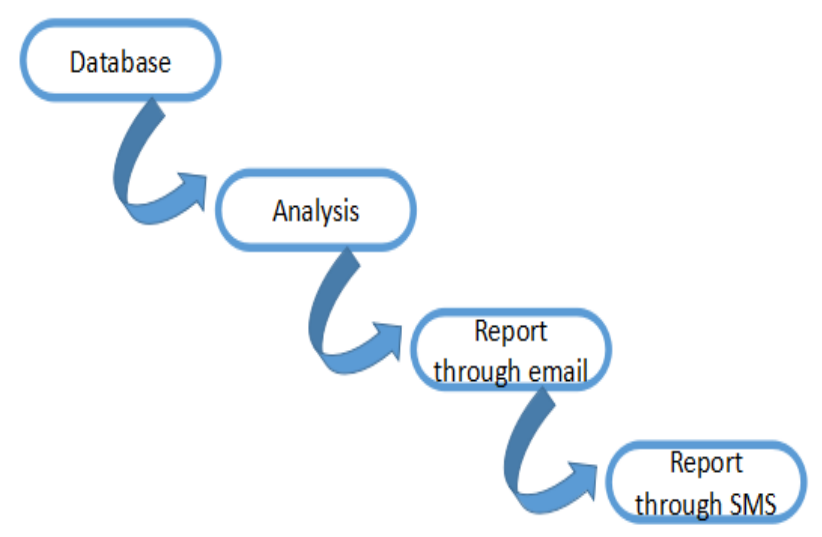

\section{SYSTEM DESIGN}

The design is simple and user friendly. It involves six modules which are explained in detail.

- Login Module

- Import file Module

- Check Student Details Module

- Addition of Details

- Short Message Service

- Electronic Mail Generator

These modules explain about the functions that are accessed by the staff. Each module has different functions to be carried out.

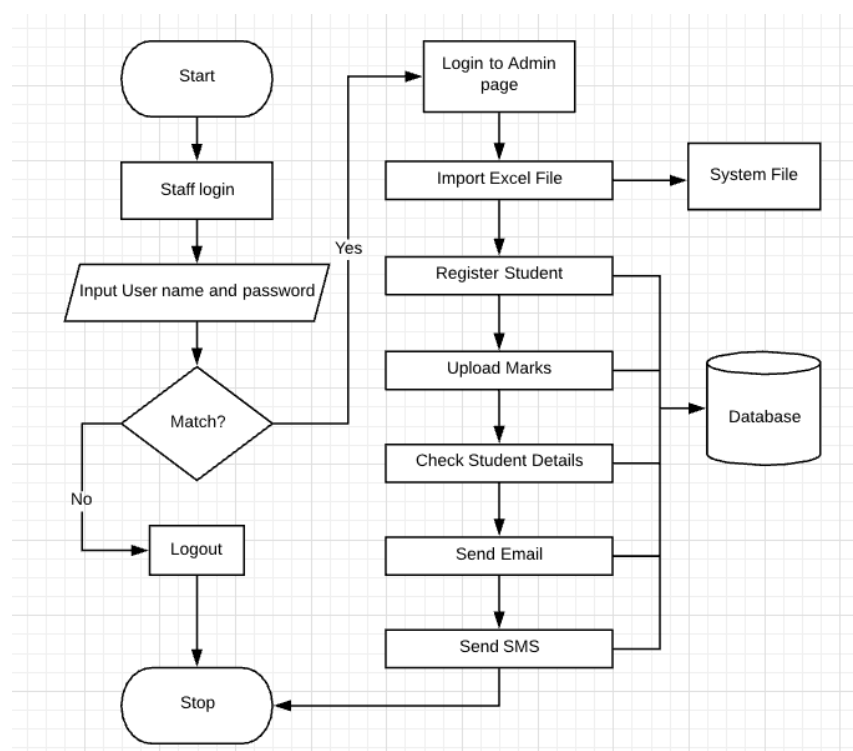

Fig. 1

\section{A. Login Page}

The login page consists of the username and password. If the given credentials match with the database then the user is ready to login and move on to the next which consists of all other module functions

\section{B. Import File}

The document or the file that contains the student details is uploaded on to the server. The file should be in CSV format. On clicking the browse option, a window opens to help the user in browsing the student detail file from their local machine and upload on to the server.

\section{Check Student Detail}

The file that is uploaded may contain details of much number of students. If the user is in need of knowing about single student, this module comes into play. The user should enter the roll number or the name of the student to view the complete details about the student that is stored in the database including marks.

\section{Addition of details}

This module reflects the register student interface where in the details of the students are entered and saved directly onto the server. This module is helpful when the user decides to add students whose details aren't present in the file uploaded. The details are stored directly on to the server and the text messages are sent.

\section{E. Short Message Service}

The system sends messages to the contact numbers that is specified in the file uploaded with the help of service provider. Bulk message API is incorporated for this purpose and also the message sent is simple and understandable. The world is diverse so are the languages spoken. This system sends the text message in Tamil as it is the state language of Tamil Nadu.

\section{F. Electronic Mail Generator}

For those parents whose mobile phone lock isn't private to their children, this module may be considered as a boon. 
Emails are always secured and here the text message is sent in English. The message species the marks scored by the student in each subjects and whether or not he/she has cleared the examinations.

\section{CONCLUSION}

A web based application has been presented for Student Mark Reporting System. The system requires less work for the teachers to contact the parents of the students. Email and Short message containing the academic score of the student is sent. Furthermore, this system brings an additional feature of sending the short message in Tamil so that the parents who are not comfortable with English can understand and participate in their children's betterment. This system has a simple user interface which enables the users to add data to the database even after uploading the file.

\section{REFERENCES}

[1] Pallavi Mohadikar, Nasrin Mulani, Afnan Shaikh, Rachna Sable, 2015 ,"College Parent Interaction using Android Application", International Journal of Computer Science and Network.

[2] Dr. D. Asir Antony Gnana Singh1 , Dr. E. Jebamalar Leavline2 P. Meera Vijayan3 ,2017,“Mobile Application for Student Attendence and Mark Management System".

[3] S.R.Bharamagoudar1 , Geeta R.B.2 , S.G.Totad, 2013, "Web Based Student Information Management System", International Journal of Advanced Research in Computer and Communication Engineering.

[4] Amita Dhale, Madhav Mistry, Tushar Zore, 2014 "A Survey on SMART CONNECTS" an Android and Web Based Application for College Management System"International Journal of Science, Engineering and Technology Research (IJSETR).

[5] Ruchi Yadav, Pradnya Ramteke, Anjali Wanjari, Abha Dongre \& Prashant Verma, 2017, "A Survey: SMS Based Student Intimation System", Imperial Journal of Interdisciplinary Research.

[6] Sanyukta Vinod Pachkawade, Rakshanda Pawan Poddar, Pragati Ganesh Bhokare, Avadhut Ashok Mendhe, Prof. Jitendra S. Saturwar, 2018, "College Interaction with Parents using Android and Web Application”,International Journal for Scientific Research \& Development(IJSRD).

[7] Vishwakarma R Ganesh,2016, “Android College Management”, International Journal of Advanced Research in Computer Engineering $\&$ Technology (IJARCET)

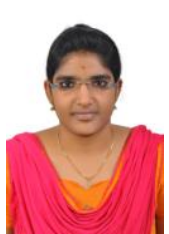

Abirami $\mathbf{V}$ is a final year student at Rajalakshmi Engineering College, Chennai, Thandalam, India. She is pursuing her Bachelor of Engineering in Computer Science and Engineering.

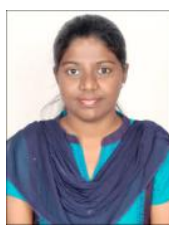

Chandhnee $\mathbf{P}$ is a final year student at Rajalakshmi Engineering College, Chennai, Thandalam, India. She is pursuing her Bachelor of Engineering in Computer Science and Engineering.

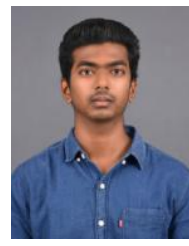

Anand $\mathbf{V}$ is a final year student at Rajalakshmi Engineering College, Chennai, Thandalam, India. He is pursuing his Bachelor of Engineering in Computer Science and Engineering.

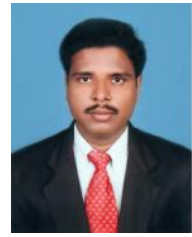

Narayana K.E, Assistant Professor, Computer Science and Engineering at Rajalakshmi Engineering College, Thandalam, Chennai, India. 